Motteram, R. (1951). F. Path. Bact., 63, 389.

Packard, R. S. (1960). Gut, 1, 171.

Palmer, E. D. (1954). Medicine (Baltimore), 33, 199.

Registrar-General (1958). The Registrar-General's Decennial Supplement, England and Wales, 1951. Occupational Mortality, Part II, Mol. 2, Tables. H.M.S.O., London.

Schoen, A. M. (1963). In Gastroenterology, Vol. 1, edited by H. L. Bockus, 2nd ed. Saunders, Philadelphia.

Siurala, M., and Seppälä, K. (1960). Acta med. scand., 166, 455.

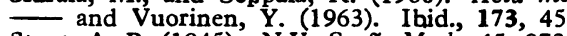

Stout, A. P. (1945). N.Y. St. $\dot{F}$. Med., 45, 973.

Stubbé, L. T. F. L. (1958). Brit. med. 尹., 2, 1062.

Sumerskili, W. H. J., and Alvarez, A. S. (1958). Lancet, 2, 925.

Taylor, K. (1961). Gastroenterology, 41, 147 .

Taylor, K. B., Roitt, I. M., Doniach, D., Couchman, K. G., and Shapland, C. (1962). Brit. med. ₹., 2, 1347

and Truelove, S. C. (1962). 'Gut, 3, 277
Valencia-Parparcén, J., and Römer, H. (1963). Amer. Y. dig. Dis., 8, 798.

Vilardell, F. (1963). In Gastroenterology, Vol. 1, edited by H. L. Bockus, 2nd ed. Saunders, Philadelphia.

Whiteside, M. G.. Mollin, D. L., Coghill, N. F., Williams, A. W., and Anderson, B. (1964). Gut, 5, 385.

Williams, A. W. (1956). Brit. med. f., 1, 256.

- Coghill, N. F., and Edwards, F.' (1958). Brit. F. Haemat., 4, 457. Edwards, F., Lewis, T. H. C., and Coghill, N. F. (1957). Brit. med. 7., 1, 372 .

Wintrobe, M. M. (1961). Clinical Haematology, 5th ed. Kimpton, London.

Wood, I. J., Doig, R. K., Motteram, R., and Hughes, A. (1949). Lancet, 1,18 .

Walston, M., Ungar, B., and Cowling, D. C. (1964). Gut, 5, 27.

ood, P. H. N., Harvey-Smith, E. A., and Dixon, A. St. J. (1962). Brit. med. 7., 1, 669.

\title{
Study of Myocardial Ischaemia in Surgical Patients
}

\author{
M. ROSEN,* M.B., F.F.A. R.C.S. ; W. W. MUSHIN,* M.B., F.F.A. R.C.S. ; G. S. KILPATRICK, † M.D., F.R.C.P.ED. \\ H. CAMPBELL, $\ddagger$ M.B., F.S.S. ; L. G. G. DAVIES,§ M.D., B.SC., M.R.C.P. ; E. HARRISON,* M.B., B.CH., F.P.A. R.C.S.
}

Brit. med. F., 1966, 2, 1415-1420

The clinician is concerned about any possible harm which anaesthesia and surgery may do to the patient with ischaemic heart disease.

Retrospective studies (dePeyster et al., 1952 ; Etsten and Proger, 1955 ; Arkins et al., 1964 ; Topkins and Artusio, 1964) have shown that patients who are known to suffer from this disease incur a considerable risk from surgery and anaesthesia, and that the likelihood of and the mortality from myocardial infarction postoperatively are much higher in them than in healthy individuals. It is therefore important to know whether a surgical patient is suffering from ischaemic heart disease. A precise history with clear electrocardiographic (E.C.G.) evidence of infarction may be obtained, but there are many patients in whom the picture is not so definite but who nevertheless may be at risk as a result of a surgical operation. However, the extent to which unrecognized and perhaps subclinical ischaemic heart disease exists in surgical patients passing through a busy hospital is not known. There are practical difficulties in conducting a detailed cardiovascular investigation of every patient, and in the majority of hospitals the most that can usually be done is a fairly rapid assessment by the anaesthetist a day or two before operation. It would therefore be valuable if "markers" could be defined which would indicate those patients who may have ischaemic heart disease, and to whom special attention should be paid by the anaesthetist preoperatively.

Previous studies (Driscoll et al., 1961 ; Chamberlain and Edmonds-Seal, 1964) have inferred that a comparatively large number of patients develop postoperative E.C.G. changes suggestive of ischaemic damage but short of frank infarction. Associations between ischaemic heart disease and such factors connected with the nature of the surgical operation as the site of operation, hypotension, and the duration of surgery were suggested in those papers. The reported incidence of E.C.G. changes ranged from $17 \%$ of general surgical patients to $43 \%$ of patients already suffering from clinical or suspected ischaemic heart disease or from severe hypertension. Many of these E.C.G. changes might have been due to minor degrees of ischaemic damage occurring in association with the surgical

- Department of Anaesthetics, Royal Infirmary, Cardiff.

t Senior Lecturer in Medicine, Tuberculosis, and Diseases of the Chest, Welsh National School of Medicine, Cardiff.

‡ Senior Lecturer in Medical Statistics, Welsh National School of Medicine, Cardiff.

$\checkmark$ Consultant Cardiologist, Sully Hospital, Glamorgan. operation. In view of the possible value of these findings in terms of ultimate prognosis, it seemed important to examine this matter further.

We therefore decided to carry out a pilot prospective study of our own hospital surgical population to determine the prevalence of myocardial ischaemia or infarction in a defined group of patients and to relate, if possible, any myocardial ischaemic changes to factors connected with the operation. Myocardial ischaemia was judged by E.C.G. and by clinical evidence not only preoperatively but also during operation and postoperatively. As a result it was hoped to define groups of patients which might be studied in more detail.

\section{Method}

This study was carried out on all patients aged 35 to 66 admitted to our surgical wards from the waiting-list during a period of four months. Emergencies and patients transferred from other wards were not included. The age range was chosen partly because these patients represent a major numerical section of the surgical work in the Cardiff Royal Infirmary. In addition, the age range extends from younger adults in whom any ischaemic heart disease may be subclinical to older adults in whom it is more likely to be overt. Any relation between surgery and cardiac ischaemia would be expected to make more evident ischaemic heart disease that might otherwise pass unrecognized.

A detailed anaesthetic record of all inpatients anaesthetized has been kept for over 15 years (Mushin et al., 1954), and the data are transferred to Hollerith cards for rapid sorting. It was an easy matter to add to this record not only E.C.G. readings but also certain specially graded factors.

The following are the data to which special attention was paid.

Preoperative Data.-(a) Blood pressure was graded as normal, moderate hypertension (either systolic over $160 \mathrm{~mm}$. $\mathrm{Hg}$ or diastolic over 100), or severe hypertension (either systolic over 200 or diastolic over 120). (b) Angina. (c) Previous myocardial infarction and the date of occurrence. (d) Obesity: height and weight tables were used to calculate relative obesity as the percentage deviation from normal (Documenta Geigy Scientific Tables, 1962).

Operative Data.-Hypotension during operation was defined as a fall of more than $25 \%$ of the preoperative systolic blood pressure 
at rest. The blood pressure was taken as a steady reading by the anaesthetist at the preoperative examination.

Postoperative Data.-The case-notes and anaesthetic record of each patient were reviewed on discharge. In addition to the complications already noted on the anaesthetic record sheet any other complications found in the case-notes were included.

E.C.G.s.-A standard 12-lead resting electrocardiogram was recorded in each patient preoperatively and postoperatively.

Most postoperative E.C.G.s were done within two days of operation, but a few were delayed for longer periods. There is considerable observer variation in the reading of E.C.G.s (Davies, 1958; Thomas et al., 1958); therefore two of us (G.S. K. and L. G. G. D.) read the preoperative and postoperative tracings. Each reader recorded his results separately, without knowledge of clinical details. If any disagreement arose the E.C.G. was reviewed by the two readers together and an "agreed reading" recorded.

The E.C.G.s were not read according to the strict criteria of, for example, the Minnesota code (Blackburn et al., 1960), but rather were interpreted in a manner on which clinical decisions would normally be based. The categories employed have limitations, but to be practical the detection of "vulnerable groups" in the population must, if at all possible, be based on some such broad classification.

The categories employed were:

1. Normal E.C.G.

2. E.C.G. with clear evidence of ischaemic heart disease-musually by evidence of myocardial infarction in the form of abnormal $Q$ waves and changes in the $S-T$ segment or $T$ wave.

3. E.C.G. evidence of "ischaemia" as shown by changes in the $S-T$ segment or $T$ wave, but which were not thought specific for ischaemic heart disease.

4. E.C.G. showing clear evidence of left ventricular hypertrophy -that is, exaggerated $R$ waves and $S-T$ segment changes or $T$-wave inversion in a left ventricular lead.

5. E.C.G. showing evidence suggestive of left ventricular hypertrophy-changes similar to but occurring to a less degree than in group 4.

6. E.C.G. showing other abnormalities such as atrial fibrillation.

Groups 4, 5, and 6 may include some subjects suffering from ischaemic heart disease.

There can be little doubt about the clear cases of ischaemic heart disease and of left ventricular hypertrophy, but perhaps more interesting is the group with the non-specific E.C.G. changes, many of which may in fact represent changes due to ischaemic heart disease (Higgins et al., 1963). Proof of this is lacking, and an extended prospective study would seem to be necessary.

E.C.G. examinations that were thought necessary by the clinician in charge of the patient were carried out in the usual way in addition to those made for this study. The latter E.C.G.s were not always read before the patient left hospital.

\section{Results}

Records were completed and preoperative and postoperative E.C.G.s obtained in 506 patients undergoing operations. (There were actually 492 patients ; 14 had two operations, but only one of them had an abnormal E.C.G.).

During this period 293 other patients were admitted from the waiting-list but did not have an E.C.G. taken. The omissions occurred at random, and were due to overloading of the E.C.G. department; but these patients were similar in every other respect-such as day of admission, operation, surgical firm, anaesthetic, sex, history, age, symptoms, nature of operation, and duration of stay in hospital-to the 506 whose records are complete. We are satisfied that the omission of the 293 patients from this study does not affect the validity of the results. It became clear that preoperative and postoperative E.C.G.s on a routine basis would not be possible without considerably expanding the E.C.G. department.

\section{Prevalence of Overt Ischaemic Heart Disease and of Myocardial Ischaemic Changes}

Table I shows the preoperative and postoperative E.C.G. findings, and Table II indicates how these were distributed by age and sex. In addition, Table II includes the distribution of those patients with clinical evidence of ischaemic heart disease. From these tables all the others are derived.

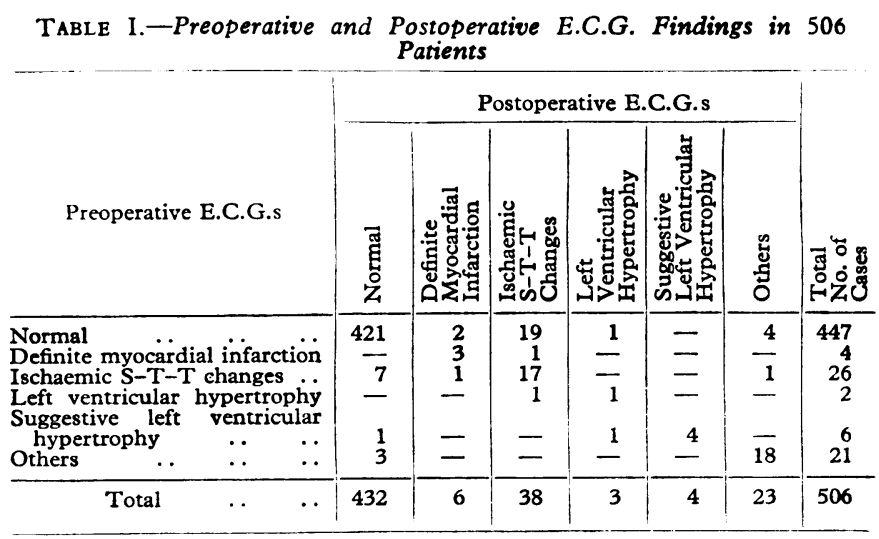

Twenty-six patients (Table III) showed evidence of ischaemic heart disease; eight of them had either a typical history or a typical residual E.C.G. A further 22 patients (Table IV) had evidence of ischaemic changes (Table II: 30 patients with preoperative ischaemic changes less 8 with clinical ischaemic heart disease). There were therefore 48 patients, or $10 \%$ of this age group, in whom these conditions were discovered preoperatively.

There were 447 patients (Table I) with preoperative normal E.C.G.s, of whom 15 had ischaemic heart disease (Table II). Therefore, of the 432 patients with normal E.C.G.s and no history of ischaemic heart disease, 19 developed E.C.G. changes either of infarction or ischaemia after operation (Table V).

The study therefore revealed a total of $67(13 \%)$ patients who showed evidence of myocardial ischaemia in some degree during their stay in hospital.

TABLE II.-Age and Sex Distribution

\begin{tabular}{|c|c|c|c|c|c|c|c|c|c|}
\hline \multirow{3}{*}{ E.C.G. Findings } & \multirow{3}{*}{$\begin{array}{l}\text { Total } \\
\text { No. }\end{array}$} & \multicolumn{8}{|c|}{ E.C.G. Findings Agc and Sex } \\
\hline & & \multicolumn{4}{|c|}{ Males } & \multicolumn{4}{|c|}{ Females } \\
\hline & & $35+$ & $45+$ & $55+$ & Total & $35+$ & $45+$ & $55+$ & Total \\
\hline 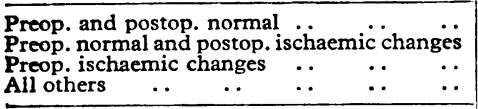 & $\begin{array}{l}421(13) \\
21(2) \\
30(8) \\
34(3) \\
\end{array}$ & $\begin{aligned} 38(0) \\
0(0) \\
1(1) \\
2(0) \\
\end{aligned}$ & $\begin{array}{r}53(4) \\
3(1) \\
2(0) \\
1(0) \\
\end{array}$ & $\begin{aligned} 68(4) \\
4(1) \\
6(3) \\
6(1) \\
\end{aligned}$ & $\begin{array}{r}159(8) \\
7(2) \\
9(4) \\
9(1) \\
\end{array}$ & $\begin{aligned} 97(1) \\
4(0) \\
5(0) \\
10(0)\end{aligned}$ & $\begin{array}{r}105(3) \\
5(0) \\
8(2) \\
6(0) \\
\end{array}$ & $\begin{aligned} 60(1) \\
5(0) \\
8(2) \\
9(2) \\
\end{aligned}$ & $\begin{array}{r}262(5) \\
14(0) \\
21(4) \\
25(2) \\
\end{array}$ \\
\hline All & $506(26)$ & $41(1)$ & $59(5)$ & $84(9)$ & $184(15)$ & $116(1)$ & $124(5)$ & $82(5)$ & $322(11)$ \\
\hline
\end{tabular}

* No of patients with ischaemic heart disease diagnosed on either clinical or electrocardiographic grounds in each subgroup are in parentheses. Details of them are given in Table III. 
Thirty-one other patients had either preoperative or postaperative evidence of left ventricular hypertrophy or disturbances of rhythm, such as atrial fibrillation, the cause of which could not clearly be connected with cardiac ischaemia. (There are 35 such patients in Table I. However, of these, three had ischaemic heart disease (Table III) and one had preoperative ischaemic changes (Table IV). These have been included in those categories.)

Thus there were 98 patients $(20 \%)$ who gave evidence of some cardiac abnormality during their stay in hospital.

Table III.-Details of 26 Patients with Ischaemic Heart Disease

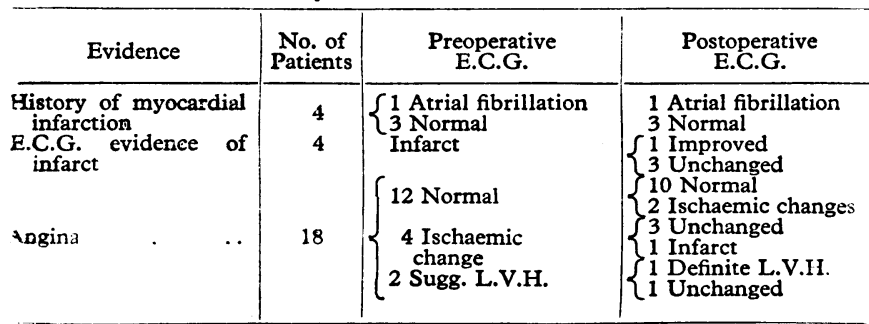

L.V.H. = Left ventricular hypertrophy.

ГABLE IV.-E.C.G. Evidence of Non-specific Ischaemic Changes (No Symptoms)

\begin{tabular}{|c|c|c|}
\hline No. of Patients & Preoperative E.C.G. & Postoperative E.C.G. \\
\hline 22 & Ischaemic changes & $\begin{array}{l}14 \text { Unchanged } \\
1 \text { Arrkythmia } \\
7 \text { Became normal } \\
\text { (all } 7 \text { females normotensive }\end{array}$ \\
\hline
\end{tabular}

TABLE V.-Prooperative E.C.G.s Normal: No History of Ischaemic Heart Disease

\begin{tabular}{c|l|r}
\hline No. of Patients & Postoperative E.C.G. & No. \\
\hline 432 & Infarct & 2 \\
& Ischaemic changes & 17 \\
Others & 5 \\
Normal & 408 \\
\hline
\end{tabular}

\section{Myocardial Infarction (Table VI)}

Eight patients, all males, had had a preoperative myocardial infarction; of these four (Cases 1-4) gave a clear history of infarction, but in three of them we found a normal E.C.G. The other four (Cases 5-8) gave no history of an infarct but showed clear E.C.G. evidence. One of these patients was a diabetic (there were four other diabetics in the series). Seven of the eight patients were over 55 years of age.
Three patients not included in these eight developed a postoperative infarct, shown on the E.C.G. All were females. Only one patient, who had transient atrial fibrillation and for whom an E.C.G. was requested, was diagnosed by the clinician. The details of these patients are shown in Table VII.

\section{Association between Revealed Ischaemic Changes and other Factors}

In all these associations the numbers were small and the trends are only suggestive.

\section{(A) Symptoms and/or History (Table VIII)}

In the decade $35+$ the prevalence of ischaemic heart disease was low in both sexes. In the next decade the prevalence increased, the male rate being about twice as high as the female. Over the age of 55 females were nearly level with males, the prevalence of symptoms or history being 6 and $7 \%$. This group represents those patients with ischaemic heart disease who could be discovered upon clinical consideration alone.

TABLE VIII.-Percentage of Patients with Symptoms or History in Each

\begin{tabular}{ll|c|c|c|c|c|c}
\hline & \multicolumn{2}{|c|}{ Age Group } \\
\hline & & No. & $\%$ & \multicolumn{2}{|c|}{$45+$} & \multicolumn{2}{|c}{$55+$} \\
\hline Males .. & $\ldots$ & 0 & 0 & 5 & 9 & 6 & 7 \\
\hline Females &. & 1 & 1 & 5 & 4 & 5 & 6
\end{tabular}

\section{(B) E.C.G. Evidence (Table IX)}

Age and Sex.-The association here is strikingly different: females preponderate in each age group, particularly in the $35+$ group, where the female rate is over three times that of males. The overall prevalence of E.C.G. evidence increases with age, until in the $55+$ group it is found in $12 \%$ of males and $16 \%$ of females.

Operative Procedures.-(a) Surgical Operation: The four operations with the highest prevalence of E.C.G. ischaemic changes are shown in Fig. 1. (b) Anaesthetics (Table X): The standard practice was nitrous oxide and oxygen, thiopentone, and analgesic relaxant, either with or without halothane: 57 patients $(11 \%)$ received this combination without halothane.

TABLE VI.-Previous Myocardial Infarction (Preoperative)

\begin{tabular}{|c|c|c|c|c|c|c|c|c|c|}
\hline $\begin{array}{l}\text { Case } \\
\text { No. }\end{array}$ & $\begin{array}{l}\text { Sex } \\
\text { and } \\
\text { Age }\end{array}$ & B.P. & $\begin{array}{l}\text { Preop. } \\
\text { E.C.G. }\end{array}$ & $\begin{array}{c}\text { Symptoms } \\
\text { or } \\
\text { History }\end{array}$ & $\begin{array}{l}\text { Interval } \\
\text { Since } \\
\text { Infarct }\end{array}$ & Operation & $\begin{array}{c}\text { Duration } \\
\text { of } \\
\text { Operation }\end{array}$ & $\begin{array}{l}\text { Postop. } \\
\text { E.C.G. }\end{array}$ & $\begin{array}{l}\text { Postop. } \\
\text { Course }\end{array}$ \\
\hline$\frac{1}{2}$ & $\begin{array}{ll}M & 62 \\
M & 61\end{array}$ & $\begin{array}{l}190 / 115 \\
180 / 105\end{array}$ & $\begin{array}{c}\text { Normal } \\
\text { Atrial fibrillation }\end{array}$ & $\begin{array}{ll}\text { Angina. } & \text { Infarct } \\
\text { Angina. } & \text { Infarct }\end{array}$ & $\begin{array}{l}8 \text { months } \\
16 \text { years }\end{array}$ & $\begin{array}{l}\text { Cystoscopy } \\
\text { Removal pharyngeal }\end{array}$ & $\begin{array}{l}10 \text { minutes } \\
2 \text { hours }\end{array}$ & $\begin{array}{l}\text { Normal } \\
\text { Atrial } \\
\text { fibrillation }\end{array}$ & $\begin{array}{c}\text { Uneventful } \\
,\end{array}$ \\
\hline $\begin{array}{l}3 \\
4 \\
5 \\
6\end{array}$ & $\begin{array}{ll}M & 58 \\
M & 57 \\
M & 61 \\
M & 65\end{array}$ & $\begin{array}{l}120 / 85 \\
135 / 80 \\
160 / 90 \\
190 / 100\end{array}$ & $\begin{array}{l}\text { Normal } \\
\text { Old”infarct } \\
", \quad,\end{array}$ & $\begin{array}{l}\text { Infarct } \\
\text { Angina. Infarct } \\
\text { None (diabetes- } \\
\text { None (diabet }\end{array}$ & $\begin{array}{l}9 \\
5\end{array}$ & $\begin{array}{l}\text { Sigmoidoscopy } \\
\text { Cystoscopy } \\
\text { Prostatectomy } \\
\text { Block dissection } \\
\text { glands of neck }\end{array}$ & $\begin{array}{l}10 \text { minutes } \\
10 \text {," } \\
1 \text { hour } \\
2 \frac{1}{2} \text { hours }\end{array}$ & $\begin{array}{l}\text { Normal } \\
\text { Improved } \\
\text { Unchanged }\end{array}$ & \\
\hline $\begin{array}{l}7 \\
8\end{array}$ & $\begin{array}{ll}M & 63 \\
M & 36\end{array}$ & $\begin{array}{l}195 / 100 \\
130 / 80\end{array}$ & $", \quad$, & None & $\overline{-}$ & $\begin{array}{l}\text { L.I.H. } \\
\text { Bilateral I.H. }\end{array}$ & $\begin{array}{l}1 \text { hour } \\
2 \text { hours }\end{array}$ & ", & , \\
\hline
\end{tabular}

TanL VII.-Postoperative Myocardial Infarctions (E.C.G. Evidence)

\begin{tabular}{|c|c|c|c|c|c|c|}
\hline $\begin{array}{l}\text { Sex } \\
\text { and } \\
\text { Age }\end{array}$ & B.P. & $\begin{array}{c}\text { Pre- } \\
\text { operative } \\
\text { E.C.G. }\end{array}$ & $\begin{array}{c}\text { Symptoms } \\
\text { or } \\
\text { History }\end{array}$ & Operation & $\begin{array}{c}\text { Duration } \\
\text { of } \\
\text { Operation }\end{array}$ & $\begin{array}{c}\text { Post- } \\
\text { operative } \\
\text { Course }\end{array}$ \\
\hline F 49 & $150 / 80$ & Normal & $\begin{array}{l}\text { Thyrotoxi- } \\
\text { cosis }\end{array}$ & $\begin{array}{r}\text { Thyroid- } \\
\text { ectomy }\end{array}$ & 2 hours & Atrial fibril \\
\hline F 44 & $110 / 70$ & ” & None & Incisional & 1 hour & $\begin{array}{l}24 \text { hours } \\
\text { Undiag- }\end{array}$ \\
\hline F 58 & $180 / 90$ & $\begin{array}{c}\text { Ischaemic } \\
\text { changes }\end{array}$ & Angina & $\begin{array}{l}\text { Chole- } \\
\text { cystectomy }\end{array}$ & $1 \%$ & losed \\
\hline
\end{tabular}

TABLB IX.-E.C.G. Evidence of Ischaemic Changes or of Infarction.

\begin{tabular}{|c|c|c|c|c|c|c|c|c|}
\hline \multirow{2}{*}{$\begin{array}{l}\text { Age } \\
\text { Group }\end{array}$} & \multicolumn{3}{|c|}{$\begin{array}{c}\text { Preop. E.C.G. } \\
\text { Evidence }\end{array}$} & \multicolumn{3}{|c|}{$\begin{array}{l}\text { Preop. Normal/Postop. } \\
\text { E.C.G. Evidence }\end{array}$} & \multicolumn{2}{|c|}{ Total } \\
\hline & Sex & No. & $\%$ & Sex & No. & $\%$ & No. & $\%$ \\
\hline $35+$ & $\left\{\begin{array}{l}\text { Male } \\
\text { Female }\end{array}\right.$ & $\begin{array}{l}1 \\
5\end{array}$ & $\begin{array}{l}2 \\
4\end{array}$ & $\left\{\begin{array}{l}\text { Male } \\
\text { Female }\end{array}\right.$ & $\begin{array}{l}0 \\
4\end{array}$ & $\begin{array}{l}\mathbf{0} \\
\mathbf{3}\end{array}$ & $\begin{array}{l}1 \\
9\end{array}$ & $\begin{array}{l}2 \\
7\end{array}$ \\
\hline $45+$ & $\left\{\begin{array}{l}\text { Male } \\
\text { Female }\end{array}\right.$ & $\begin{array}{l}2 \\
8\end{array}$ & $\begin{array}{l}3 \\
7\end{array}$ & $\left\{\begin{array}{l}\text { Male } \\
\text { Female }\end{array}\right.$ & $\begin{array}{l}3 \\
5\end{array}$ & $\begin{array}{l}5 \\
4\end{array}$ & $\begin{array}{r}5 \\
13\end{array}$ & $\begin{array}{r}8 \\
11\end{array}$ \\
\hline $55+$ & $\left\{\begin{array}{l}\text { Male } \\
\text { Female }\end{array}\right.$ & $\begin{array}{l}6 \\
8\end{array}$ & $\begin{array}{r}7 \\
10\end{array}$ & $\left\{\begin{array}{l}\text { Male } \\
\text { Female }\end{array}\right.$ & $\begin{array}{l}4 \\
5\end{array}$ & $\begin{array}{l}5 \\
6\end{array}$ & $\begin{array}{l}10 \\
13\end{array}$ & $\begin{array}{l}12 \\
16\end{array}$ \\
\hline
\end{tabular}


Only $18(4 \%)$ had combinations of other anaesthetics. There was no association between the choice of anaesthetic and E.C.G. changes.

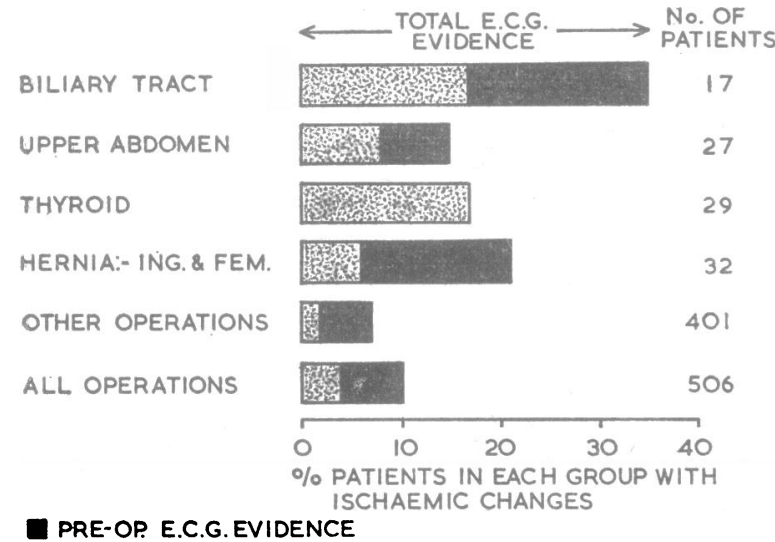

PRE-OP ECG EVIDENCE

PRE-OP. NORMAL POST-OP. E.C.G. EVIDENCE

FIG. 1.-E.C.G. evidence of ischaemic changes or of infarction and site of operation.

TABLE X.-Anaesthetics and E.C.G. Findings

\begin{tabular}{|c|c|c|c|c|}
\hline \multirow{2}{*}{ E.C.G. } & \multicolumn{2}{|c|}{$\begin{array}{c}\mathrm{N}_{2} \mathrm{O} / \mathrm{O}_{2} \pm \text { Thiopentone } \pm \\
\text { Analgesic } \pm \text { Relaxant }\end{array}$} & \multirow{2}{*}{$\begin{array}{c}\text { Other } \\
\text { Anaesthetics }\end{array}$} & \multirow{2}{*}{ Tota } \\
\hline & $\begin{array}{c}\text { With } \\
\text { Halothane }\end{array}$ & $\begin{array}{c}\text { Without } \\
\text { Halothane }\end{array}$ & & \\
\hline \multirow{3}{*}{$\begin{array}{l}\text { Preop. and postop. normal } \\
\text { Preop. normal and post- } \\
\text { op. ischaemic changes } \\
\text { Preop. normal and post- } \\
\text { op. other changes } \\
\text { Preop. ischaemic changes } \\
\text { Preop. "others" change }\end{array}$} & $87 \%(364)$ & $10 \%(44)$ & $3 \%(13)$ & $100 \%(421)$ \\
\hline & $91 \%(19)$ & $9 \%(2)$ & $0 \%(0)$ & $100 \%$ \\
\hline & $\begin{array}{l}40 \%(2) \\
73 \%(22) \\
83 \% \text { (24) }\end{array}$ & $\begin{array}{l}20 \%(1) \\
20 \%(6) \\
14 \%(4)\end{array}$ & $\begin{array}{l}40 \%(2) \\
7 \%(2) \\
3 \%(1)\end{array}$ & $\begin{array}{l}100 \%(5) \\
100 \%(30) \\
100 \%(29)\end{array}$ \\
\hline Total .. & $85 \%(431)$ & $11 \%(57)$ & $4 \%(18)$ & $100 \%(506)$ \\
\hline
\end{tabular}

Blood Pressure (Table XI).- The patients were divided into three groups according to their systolic and diastolic pressures (see above); no allowance was made for age. The prevalence of preoperative E.C.G. changes suggests that there was a rise with the degree of hypertension, from $5 \%$ of the normotensives to $9 \%$ of those with severe hypertension. On the other

TABLB XI.-E.C.G. Evidence of Ischaemic Changes or of Infarction Blood Pressure

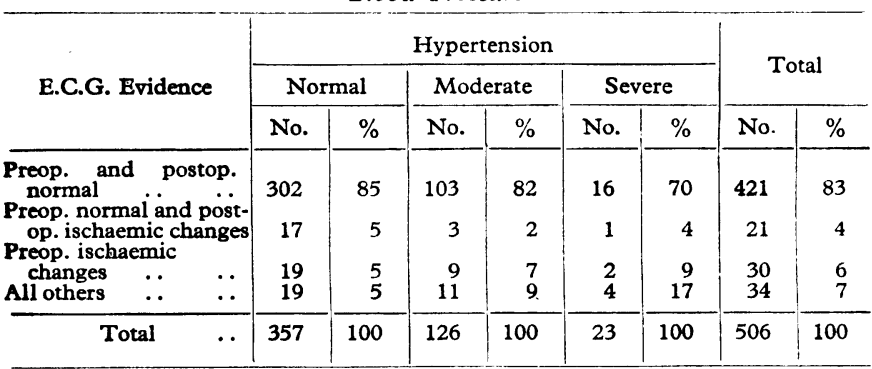

hand, the ischaemic changes which appeared postoperatively did not show any increase between normotensives and severe hypertensives. Nearly $30 \%$ of the patients studied had moderate or severe hypertension. The proportion of patients in each group with a normal E.C.G. preoperatively and postoperatively fell steadily to $70 \%$ in the severe-hypertension group.

\section{Obesity (Fig. 2)}

The patients were divided into seven categories, three on either side of "normal" (see above). The incidence of E.C.G. changes in the normal group was $11 \%$. There does not seem to be any clear relation between the degree of obesity and the incidence of E.C.G. changes. However, the incidence of the changes in all the patients who were overweight was slightly higher $(12 \%)$ than the normal, while in the patients who were underweight it was slightly lower $(9 \%)$. We noted with interest that $12 \%$ of all the patients were more than $20 \%$ overweight.

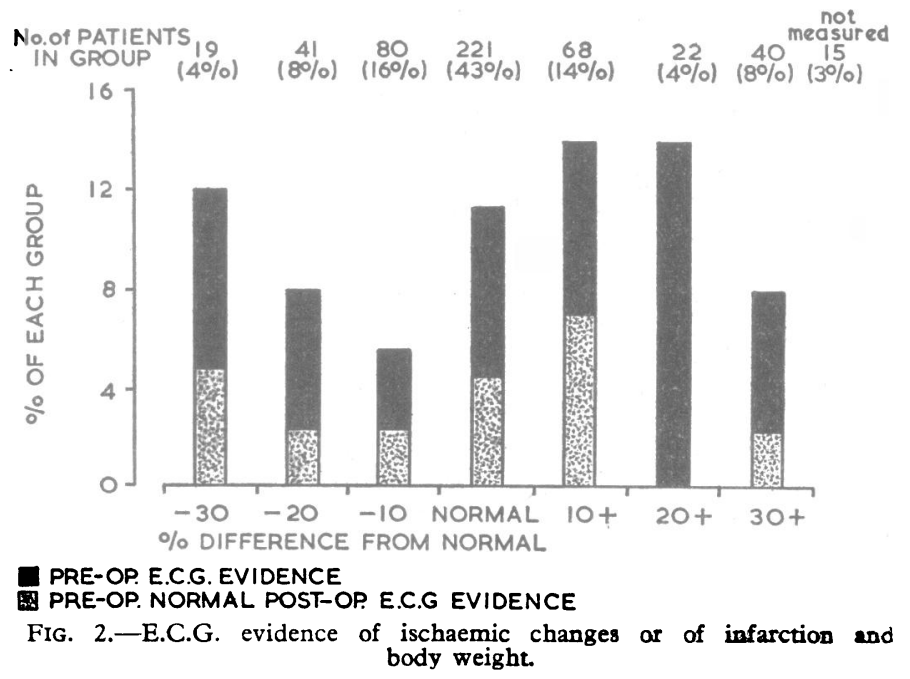

\section{Duration of Operation (Table XII)}

The operations were arbitrarily divided on a basis of our clinical experience into those lasting less than one hour and those lasting more than one hour. Broadly speaking, this also divided surgical operations into those that are less or more

TABLE XII.-E.C.G. Evidence of Ischaemic Changes or of Infarction

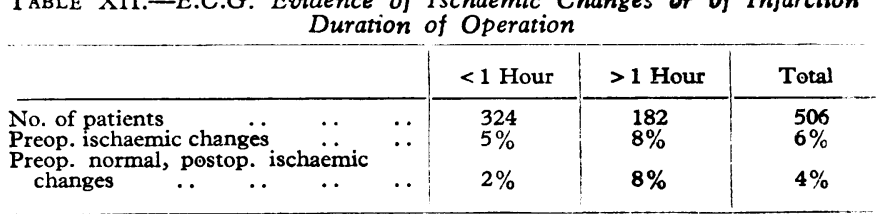

serious. The incidence of preoperative E.C.G. changes was higher in those undergoing longer operations. The patient whose operations were prolonged also showed a much higher total incidence $(16 \%)$ of postoperative ischaemic changes.

\section{E.C.G. Requests (Table XIII)}

It is clear that only a small proportion of patients whose E.C.G.s were abnormal as revealed by this study had an E.C.G.

TABLE XIII.-Requests for E.C.G. by Clinician and Findings in Survay

\begin{tabular}{|c|c|c|c|c|c|c|c|}
\hline & & \multicolumn{3}{|c|}{ Preoperative } & \multicolumn{3}{|c|}{ Postoperative } \\
\hline & & \multirow{2}{*}{$\begin{array}{l}\text { Total } \\
\text { No. }\end{array}$} & \multicolumn{2}{|c|}{ Requests } & \multirow{2}{*}{$\begin{array}{l}\text { Total } \\
\text { No. }\end{array}$} & \multicolumn{2}{|c|}{ Requests } \\
\hline & & & No. & $\%$ & & No. & $\%$ \\
\hline $\begin{array}{lc}\text { Normal } & \ldots \\
\text { Infarct .. } & \ldots \\
\text { Ischaemic changes } \\
\text { Others .. }\end{array}$ & $\begin{array}{l}\ldots \\
\cdots \\
\cdots\end{array}$ & $\begin{array}{r}447 \\
4 \\
26 \\
29\end{array}$ & $\begin{array}{r}37 \\
1 \\
3 \\
7\end{array}$ & $\begin{array}{r}8 \\
25 \\
12 \\
24\end{array}$ & $\begin{array}{r}432 \\
6 \\
38 \\
30\end{array}$ & $\begin{array}{l}5 \\
1 \\
1 \\
2\end{array}$ & $\begin{array}{r}1 \\
17 \\
3 \\
7\end{array}$ \\
\hline Total & $\ldots$ & 506 & 48 & 10 & 506 & 9. & 2 \\
\hline
\end{tabular}

requested by the clinician. Of the 59 patients who had some abnormality of their E.C.G. preoperatively, in only 11 was there a request for this investigation.

Postoperatively the number of requests was even fewer. Of 74 patients with an abnormal E.C.G. postoperatively, in only four was an E.C.G. asked for. 


\section{Hypotension During Operation}

Of the 506 patients 111 had an episode of hypotension of $25 \%$ or more from their initial systolic blood pressure. The proportion of these patients who had preoperative E.C.G. changes was $5 \%$, and another $5 \%$ had E.C.G. changes postoperatively. These figures were nearly identical with those of the 395 patients who did not have any hypotension during operation.

\section{Other Observations}

Only one patient in this study died in hospital, the cause being carcinomatosis. The duration of stay in hospital and the Incidence of complications peculiar to the various operations showed no association with the presence or absence of E.C.G. changes.

Apart from the one case identified clinically as having postoperative myocardial infarction there was no clinical evidence, ercept the arrythmias, that the E.C.G. changes had taken place.

\section{Discussion}

This study has shown the extent of myocardial infarction in our surgical patients in the age group 35-66 years. Almost balf of all our surgical patients fall into this age group.

Our anaesthetic records in this 750-bed University hospital group show that about 12,000 operations a year are carried out on patients who stay at least one night. About $50 \%$ of these are within the age groups of this investigation-that is, some 6,000 patients a year. As 8 of our 506 patients had a preoperative myocardial infarction, if this observation is extrapolated approximately 100 patients with myocardial infarction are anaesthetized each year. These figures do not take into account emergencies and older patients, who are almost certainly at greater risk. Our results show that only about half of these are likely to be recognized. On the same calculations nearly 40 patients are likely to develop a myocardial infarct after operation, and very few of these would be diagnosed.

The eight patients in Table VI seemed none the worse for their operation. Among the four patients who gave a history of infarction, the shortest interval was eight months, the other Intervals being five years and more. From the studies of Topkins and Artusio (1964) an interval of less than two years before operation carries with it a high probability of the occurrence of a second infarction. Of the three patients who developed infarction postoperatively (Table VII) two had no history and had normal E.C.G.s preoperatively. Two were diagnosed only as part of this study.

To examine the possibility that surgery was thought inadvisable in patients with known ischaemic heart disease, we compared the prevalence of myocardial infarction in our patients with those in the similar age range in the Framingham, U.S.A., population study (Dawber et al., 1957) (Table XIV). Though the bases for comparison are not identical, the prevalence of Infarction (E.C.G. and history) in our male population $45+$

TABLE XIV.-Prevalence of Myocardial Infarction in Relation to Age

\begin{tabular}{|c|c|c|c|c|c|}
\hline \multirow{2}{*}{$\begin{array}{c}\text { Age } \\
\text { Groups }\end{array}$} & \multirow{2}{*}{$\begin{array}{c}\text { Diagnoses } \\
\text { by }\end{array}$} & \multicolumn{2}{|c|}{ Males (per 1,000) } & \multicolumn{2}{|c|}{ Females (per 1,000) } \\
\hline & & $\begin{array}{c}\text { Framingham } \\
\text { Study }\end{array}$ & $\begin{array}{c}\text { Cardiff } \\
\text { Hospital }\end{array}$ & $\underset{\text { Study }}{\text { Framingham }}$ & $\begin{array}{c}\text { Cardiff } \\
\text { Hospital }\end{array}$ \\
\hline \multirow[t]{2}{*}{$30-44 *\{$} & $\begin{array}{l}\text { History o. } \\
\text { E.C.G. onily } \\
\end{array}$ & $\begin{array}{l}2 \\
1\end{array}$ & $\stackrel{0}{24 t}$ & $\begin{array}{l}0 \\
1\end{array}$ & $\begin{array}{l}\mathbf{0} \\
\mathbf{0}\end{array}$ \\
\hline & Total & 3 & 24 & 1 & 0 \\
\hline \multirow[t]{2}{*}{$45-62 *\{$} & $\begin{array}{l}\text { History } \text { E.C.G. oniy } \\
\end{array}$ & $\begin{array}{l}16 \\
11 \\
\end{array}$ & $\begin{array}{l}28 \\
21\end{array}$ & $\begin{array}{l}1 \\
6\end{array}$ & $\begin{array}{l}0 \\
0\end{array}$ \\
\hline & Total & 27 & 49 & 7 & 0 \\
\hline
\end{tabular}

- In Cardiff study, age groups 35-44 and 45-66.

t One patient. years is higher (49 per 1,000) than in the Framingham study (E.C.G. and history) ( 27 per 1,000). It therefore seems that, in the case of males at any rate, there is no evidence that patients with infarction were excluded from surgery.

A striking feature of the present study, as well as of others (Driscoll et al., 1961), is the comparatively large number of patients with normal preoperative E.C.G.s who developed nonspecific changes in the $S-T$ segment and $T$ wave suggestive of myocardial ischaemic changes. On the basis of the results, there might be 250 such patients a year in our hospital. There might also be about 300 patients with these E.C.G. changes before operation, of whom the greater number remain with an abnormal E.C.G. after operation. We have not attempted to interpret these E.C.G.s in terms of degrees of improvement or deterioration, as have other authors (Chamberlain and Edmonds-Seal, 1964), with the exception of clear myocardial infarction or a return to a normal recording. On the other hand, although from a clinical point of view there was no indication that the abnormal non-specific E.C.G.s indicated any disturbance of cardiac function, nevertheless, considering the number of patients involved and the possibility that these E.C.G. changes . indicate some subclinical cardiac damage, it seems important to investigate further whether the long-term prognosis of these patients is affected by the operative experience.

Some experts have advocated exercise tests and preoperative E.C.G.s for every surgical patient (Master and Rosenfeld, 1964). Our experience in this study has shown that to do this would require not only a larger clinical team but a considerably expanded E.C.G. department. It is clearly inadequate to rely on requests for an E.C.G. from the clinician. Even in patients with arrhythmia and a history of precordial pain and angina our records show that, preoperatively, in only one in four was there such a request. E.C.G.s are clearly not commonly asked for before operation. They are even less so after operation (Table XIII). Short of this, each operating-theatre and recovery-room might be equipped for electrocardiography. This would go some way not only to familiarize the anaesthetist and his colleagues in the surgical team with the effects of the procedure on the E.C.G. but would warn them if these changes occurred.

If in the further study of this problem the E.C.G. is to be used economically as a tool for the detection of patients with ischaemic changes or with infarction the clinician should have "markers" to indicate which patients justify more detailed investigation. A few possibilities in this direction emerge from this study, as follows:

1. Site of operation: biliary tract, hernia, thyroid, upper abdomen.

2. Duration of operation: over one hour.

3. Sex: women show a higher prevalence than males of E.C.G. changes.

4. Age: the prevalence increases with age, being more pronounced over 45 years.

5. History of angina: of 18 patients six had or developed ischaemic changes and another two had changes of left ventricular hypertrophy. One patient developed an infarction.

6. Blood pressure: patients with hypertension.

\section{Conclusions}

The following points emerged from a clinical and E.C.G. study of 506 surgical patients aged 35 to 66 years from the waiting-list.

1. Myocardial infarction was identified preoperatively in 16 per 1,000 patients-8 per 1,000 being undiagnosed.

2. Postoperatively myocardial infarction occurred in a further 6 per 1,000 patients, of whom 4 per 1,000 were undiagnosed. 
3. E.C.G. changes suggestive of ischaemia were present preoperatively in 52 per 1,000 , and similar changes developed postoperatively in a further 38 per 1,000 who had a normal E.C.G. before operation. A total of 114 per 1,000 had either ischaemic changes or infarction.

4. There is an apparent association between these E.C.G. changes and operation on the biliary tract, thyroid, upper abdomen, and herniae.

5. Associations also appear to exist with long operations, with preoperative hypertension, and possibly with obesity.

6. There was no clear association between the E.C.G. changes and the type of anaesthetic, the occurrence of hypotension during the operation, and such factors as the stay in hospital and postoperative complications due to the surgical diseases.

7. There was no clinical evidence of cardiac disturbance associated with the E.C.G. changes, except in one patient who developed postoperative myocardial infarction.

8. Of all the patients in this study (506) 98 (20\%), or 196 per 1,000 , had some abnormality of the E.C.G. or had a history suggestive of ischaemic heart disease while in hospital.

9. The study also revealed that $30 \%$ of our patients were moderately or severely hypertensive, and that $12 \%$ were more than $20 \%$ overweight.

10. Although there was little clinical evidence of cardiac disturbance which could be associated with the great majority of these E.C.G. changes, nevertheless the proportion of surgical patients involved is not small. It is important, therefore, to know with more certainty than at present whether these E.C.G. changes indicate an effect on the prognosis of the patient. Long-term follow-up studies are needed.

11. If the E.C.G. changes should prove to be of importance to the surgical team then every patient should have a preoperative and postoperative E.C.G. as well as a much better general clinical assessment than they do at present. In the meantime particular attention should be paid to the "markers" we have indicated, and perhaps more use should be made of E.C.G. monitors.

\section{Summary}

A total of 506 surgical patients aged 35 to 66 years were studied from the point of view of myocardial ischaemia and ischaemic heart disease. Myocardial infarction was present in eight patients preoperatively, and developed in three after operation. In addition, E.C.G. changes suggestive of ischaemia were present preoperatively in $26(5 \%)$, and developed postoperatively in a further $19(4 \%)$.

There was an apparent association between these changes and certain operative procedures, operations of longer duration, and preoperative hypertension.

It is important to know whether these E.C.G. changes indicate an effect on the prognosis of the patient. In all, $98(20 \%)$ patients had some abnormality of the E.C.G. or a history suggestive of ischaemic heart disease. Long-term follow-up studies are needed.

We would like to acknowledge the invaluable collaboration of Mr. J. Morgan and the staff of the Medical Records Department and of Miss D. M. Francis and the staff of the E.C.G. Department at the Royal Infirmary, Cardiff, and also to record our gratitude to many colleagues and the ward sisters who assisted us during this study. We gratefully acknowledge the help of the United Cardiff Hospitals Endowment Fund in defraying some of the expenses of this study.

\section{REFERENCES}

Arkins, R., Smessaert, A. A., and Hicks, R. G. (1964). F. Amer. med. Ass., 190, 485.

Blackburn, H., Keys, A., Simonson, E., Rautaharju, P., and Punsar, S. (1960). Circulation, 21, 1160.

Chamberlain, D. A., and Edmonds-Seal, J. (1964). Brit. med. f., 2, 784.

Davies, L. G. (1958). Brit. Heart f., 20, 153.

Dawber, T. R., Moore, F. E., and Mann, G. V. (1957). Amer. 7. publ. Hlth, 47, Suppl. p. 4.

dePeyster, F. A., Paul, O., and Gilchrist, R. K. (1952). Arch. Surg., 55, 448.

Documenta Geigy Scientific Tables, 1962, edited by K. Diem, 6th ed., p. 623. Geigy, Manchester.

Driscoll, A. C., Hobika, J. H., Etsten, B. E., and Proger, S. (1961). New Engl. F. Med., 264, 633 .

Etsten, B. E., and Proger, S. (1955). 7. Amer. med. Ass., 159, 845.

Higgins, I. T. T., Cochrane, A. L., and Thomas, A. J. (1963). Brit. 7. prev. soc. Med., 17, 153 .

Master, A. M., and Rosenfeld, I. (1964). F. Amer. med. Ass., 190, 494.

Mushin, W. W., Rendell-Baker, L., Lewis-Faning, E., and Morgan, J. H. (1954). Brit. F. Anaesth., 26, 298.

Thomas, A. J., Cochrane, A. L., and Higgins, I. T. T. (1958). Lancet, 2, 540 .

Topkins, M. J., and Artusio, J. F., jun. (1964). Anesth. Analg. Curr. Res., 43, 716.

\title{
Surgical Management of Prolapse in Elderly Women
}

\author{
EUAN G. ROBERTSON,* M.B., B.S., D.OBST.R.C.O.G. ; JAMES K. RUSSELL, † M.D., F.R.C.o.G.
}

In a previous communication (Russell, 1961) attention was drawn to some of the serious complications that may follow the use of vaginal pessaries in the management of prolapse in elderly women. During 1957-61 we saw in the gynaecological department several patients with cancer of the vagina, ulcerative vaginitis, pelvic cellulitis, and rectal or vaginal fistulae ; all related to the prolonged use of some form of vaginal pessary. Over the same period other elderly women were admitted to the department for treatment when they found that with advancing age their pessaries became difficult to insert and remove (because of senile vaginitis and narrowing of the introitus). And there were some whose pessaries in time failed to control the prolapse, which then became ulcerated, oedematous, and infected. Other writers have reported similar troubles associated with the prolonged use of pessaries. A vesico-vaginal fistula was caused by a Napier cup-and-stem pessary (McCullagh, 1955 ; McElin and Paalman, 1959), and Binnie (1964) reported the cases of two patients who suffered strangulation of a complete procidentia through a watch-spring pessary. Another patient retained a pessary in position for 62 years and did not know of its existence (Pritchard, 1961).

\section{Present Investigation}

In the belief that elderly women stand operative treatment surprisingly well it has long been the custom of the gynaeco-

\footnotetext{
* Gynaecological Registrar, Royal Victoria Infirmary, Newcastle upon

† Professor of Obstetrics and Gynaecology, University of Newcastle upon Tyne.
} 